Article

\title{
Defects analysis of seat belt tensioner cast body
}

\author{
Artur Soroczyński ${ }^{1, *}$, Piotr Czyżewski ${ }^{1}$, Krzysztof Rechowicz ${ }^{2}$ \\ ${ }^{1}$ Warsaw University of Technology, Poland; \\ Piotr Czyżewski, Ph.D.; piotr.czyzewski@wip.pw.edu.pl \\ ${ }^{2}$ Virginia Modeling, Analysis, and Simulation Center, Old Dominion University, Suffolk, VA, 23435 USA; \\ Krzysztof Rechowicz, Ph.D.; krechowi@odu.edu \\ * Correspondence: Artur Soroczyński, Ph.D.; asoroczy@wip.pw.edu.pl
}

Received: 10.12.2019; Accepted: 27.02.2020

\begin{abstract}
The article presents an analysis of the implementation of a selected element of the traveler safety system used in road transport. The results of metallographic tests were presented, and the state of stress introduced to the casting by means of forming the element by means of plastic forming was analyzed. An analysis of the manufacturing process was carried out indicating the risks that may lead to cracks in the material structure. Possible causes of founding defects were pointed out and possible technological solutions were pointed out in order to avoid them.
\end{abstract}

Keywords: safety system; imperfections of casting; ZnAl; pressure casting; metal forming

\section{Introduction}

The automotive industry is one of the fastest growing industries. Many materials are used in the production of motor vehicles, among others glass fibers, ceramics, plastics, leather. The leading trend is to reduce the weight of the entire vehicle to reduce the emission of gaseous pollutants into the atmosphere. The materials used, despite their high strength, can be machined, which gives great opportunities in the process of manufacturing components with complex shapes. The use of materials with lower density and increased strength causes that the target mass of the vehicle decreases, which leads to both reduction of the target product manufacture costs, reduction of energy consumption of the entire production process, but also to the comfort of use and ergonomics of the vehicle [7]. As a result, you can increase vehicle performance while reducing fuel consumption. Combustion of the fuel mixture is one of the factors causing the production of gaseous pollutants. The main pollutants in the gaseous state are mainly: carbon dioxide $\mathrm{CO}_{2}$, sulfur dioxide $\mathrm{SO}_{2}$, nitrogen oxide $\mathrm{NO}_{x}$ and $\mathrm{C}_{n} \mathrm{H}_{\mathrm{m}}$ hydrocarbons. [10,11]. To meet the needs of users who expect ecological solutions used in their cars, manufacturers began to gradually use modern materials in their constructions, among others: reinforced steel, aluminium alloys, magnesium alloys, composites, plastics from biodegradable materials [15].

Studies of the German foundry industry, which is one of the dominant foundry industries in Europe, prove that nearly $70 \%$ of all products manufactured in this sector are sold in the automotive industry. Car parts are usually made of aluminium alloys (over 65\%), magnesium (19\%) and zinc (9\%). At the turn of 2016 and 2017, sales and production of castings in German pressure foundries increased in many areas. According to research conducted in the first three quarters of 2017, the production of aluminium alloy castings increased by $1.2 \%$ (up to 494000 tonnes), magnesium alloys - by $4.5 \%$ (up to 13800 tonnes), and zinc alloys - by $11.6 \%$ (up to 47700 tonnes) [3]. It is important that the materials used have a lower weight and usually better strength properties, but also ensure safety and convenience of use. Ecological issues remain an additional aspect, i.e. the components or manufacturing techniques used are expected to be environmentally friendly $[4,8,19,20]$.

The assessment of the safety of use will be carried out on the example of the belt tensioner assembly, and more specifically on the casting, which is its main part.

\section{Analysis of the seat belt tensioner design}

Today, all manufactured vehicles use various solutions that are designed to provide the best protection to those inside in the event of a road collision. Appropriate seat and head restraint constructions, body constructions, gas cushions as well as multi-stage restraint systems, i.e. tensioners, are used. The seat belt 
tensioner is an additional or built-in device whose task is to tighten the seat belt webbing in order to reduce its slack during a collision. Due to various construction solutions, there are piston, ball, rack, Wankel and belt tensioners. The most popular are two types: ball and piston tensioners.

In the ball tensioner, when activated, the generator activates a set of balls that rotate the spool connected to the belt pulley. Due to the rotary movement, the belt curls up by a precisely defined section. The balls fall into the container, excluding causing any damage. [6] In the device shown in figure 1, the energy needed for movement is transmitted using a gear attached to the belt spool. At the beginning, the balls are in the tube, at the moment of collision the explosion pushes them out, and then the falling balls set in motion the gear wheel rigidly connected to the drum on which the belt was wound. As a result of the activation of the pyrotechnic charge, structural damage may occur, which was a premise to undertake research aimed at explaining the causes of such damage. Figure 2 shows the elements of the tensioner after activation of the pyrotechnic charge.

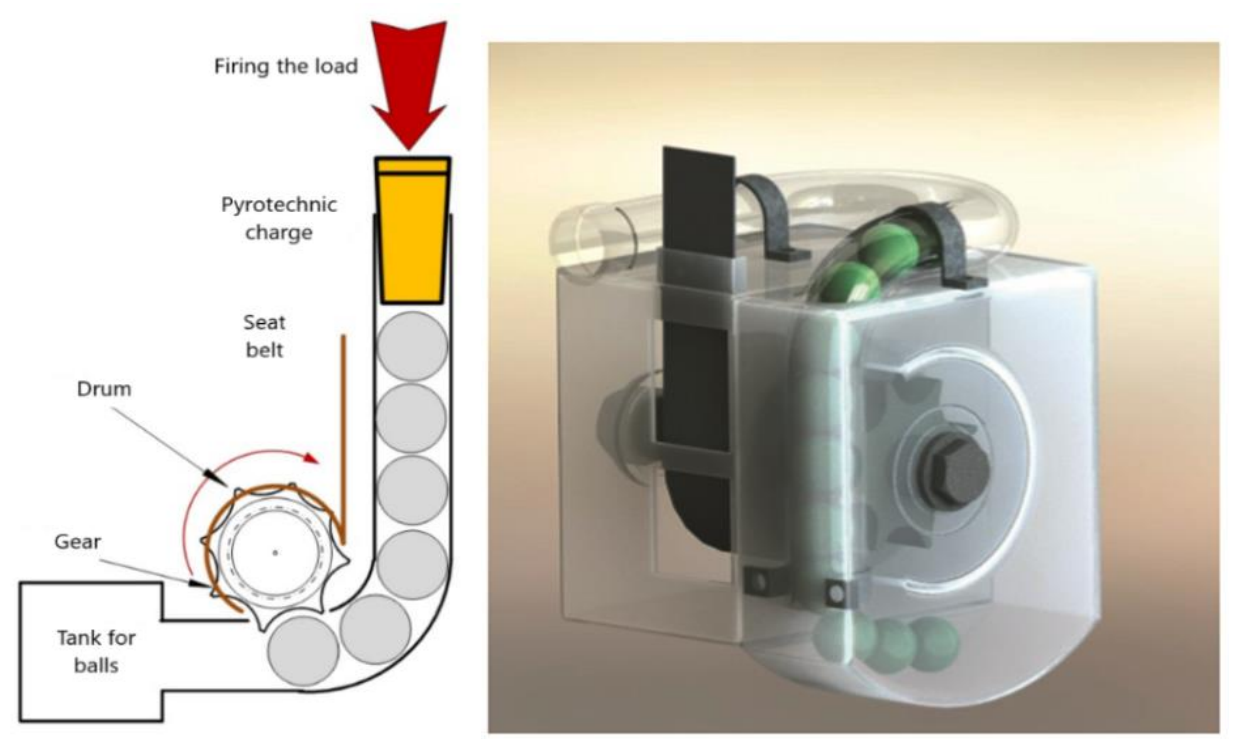

Fig. 1. Construction of a seat belt tensioner [6]

It turns out that as a result of proper operation of the tensioner, the structure of the casting, from which the body is made, is damaged. The place of damage suggests that this is the result of forces created as a result of a sharp increase in pressure caused by the explosion of a pyrotechnic charge. In order to clarify the reasons for such damage, the focus was on analyzing the technological process of manufacturing this element. In addition, metallographic tests were carried out to identify any material defects.

In order to determine the manufacturing process of the part shown in figure 2, destructive tests were carried out to show how the pyrotechnic charge was installed in the casting body. Figure 3 shows the cut element along the object's symmetry axis.

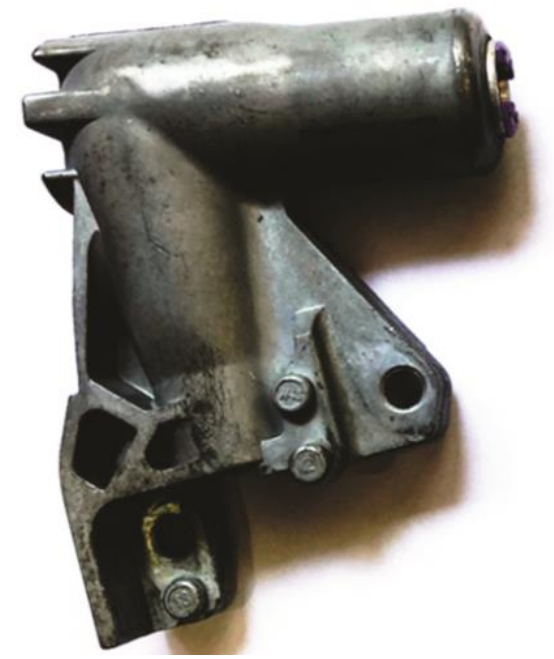

(a)

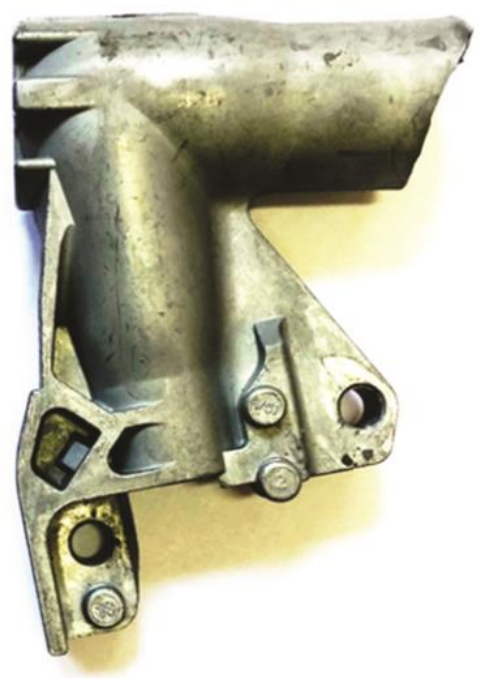

(b)

Fig. 2. Belt tensioner element: a) no damage b) visible material damage 


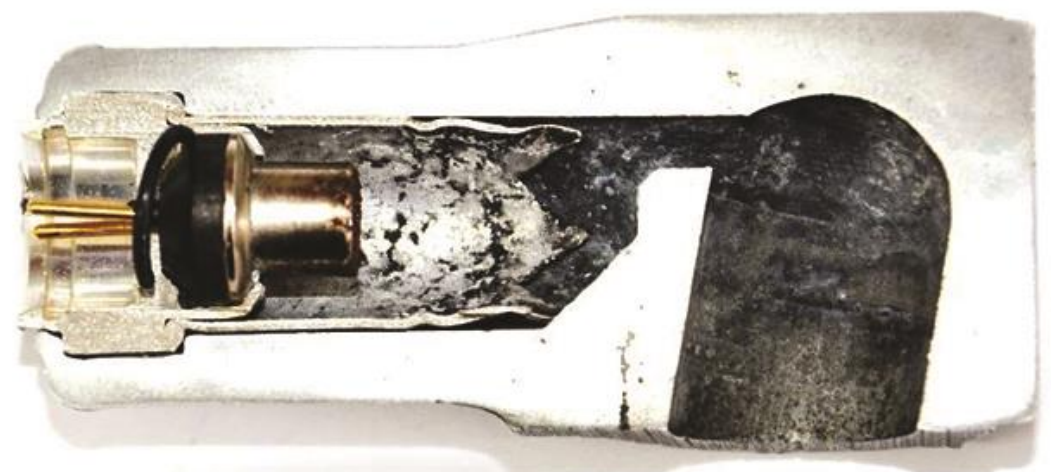

Fig. 3. The method of securing the pyrotechnic charge in a cast housing

After examination, it was found that the pyrotechnic charge could be mounted in the body only by plastic closing of the fastening lock from the upper surface. This suggests that the technological process of producing the target element requires the use of a casting as a base, then pre-attaching the assembly responsible for producing the combustion gases of the mixture and in the final stage, as a result of plastic forming, closing the upper edge of the lock in order to permanently connect all the elements.

\section{Material tests}

The first step was to determine the material from which the casting was made. After the inspection, a material designation was found that corresponds to the ZP0410 zinc alloy according to PN-EN 12844: 2001. The material properties and chemical composition are given in table I.

\begin{tabular}{|c|c|c|}
\hline Tensile strength $\mathrm{Rm}$ [MPa] & 330 & \\
\hline Density $\left[\mathrm{g} / \mathrm{cm}^{3}\right]$ & 6.7 & \\
\hline Fusion range $\left[{ }^{\circ} \mathrm{C}\right]$ & $379 \div 388$ & \\
\hline Coefficient of thermal expansion $\left[\mu \mathrm{m}^{*} \mathrm{~m}^{-1 *} \mathrm{~K}^{-1}\right]$ & 27 & \\
\hline \multirow[t]{5}{*}{ Chemical composition [wt. \%] } & $\operatorname{Tin}(S n) \leq 0.002$ & Cadmium $(C d) \leq 0.03$ \\
\hline & Lead $(\mathrm{Pb}) \leq 0.005$ & Iron $(\mathrm{Fe}) \leq 0.005$ \\
\hline & Magnesium $(\mathrm{Mg}) 0.025 \div 0.06$ & Copper $(\mathrm{Cu})<=0.05$ \\
\hline & Silicon $(\mathrm{Si}) \leq 0$ & Aluminium (Al) $0.7 \div 1.2$ \\
\hline & Zinc - the rest & Nickel (Ni) 3.7־4.3 \\
\hline
\end{tabular}

ZP0410 zinc alloy is a construction material used for high accuracy pressure castings, which confirms the correct material designation. Surface observations and structure observations were made. A $2 \% \mathrm{HF}, 2 \%$ HNO3, 96\% H2O solution was used to digest the samples. Microscopic observations were made using an Olympus IX70 microscope. Pictures were taken with a camera connected to a computer. Image processing and preview was available using the analySIS program.

Surface observations showed a number of surface porosity defects (Fig. 4). Particular attention should be paid to the fact that the defects were present in the entire cross-section examined. The porosity was characterized by an oval structure typical of defects in the pressure casting process. The largest single void was $571 \mu \mathrm{m}$, while larger clusters consisting of smaller porosities could also be observed.
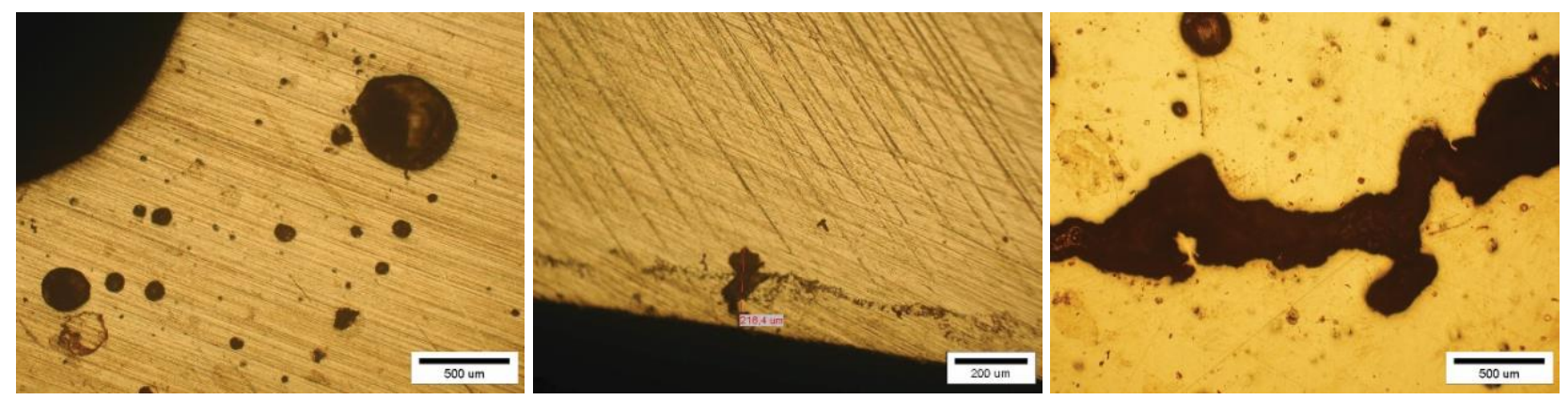

Fig. 4. Macroscopic observation of casting surface 
Figure 5 presents a view of the cast microstructure obtained after etching. This is a typical structure of a zinc alloy cast in a pressure machine, which is confirmed by the literature analysis [14]. The material resulting from the casting designations was thus confirmed by structure testing.

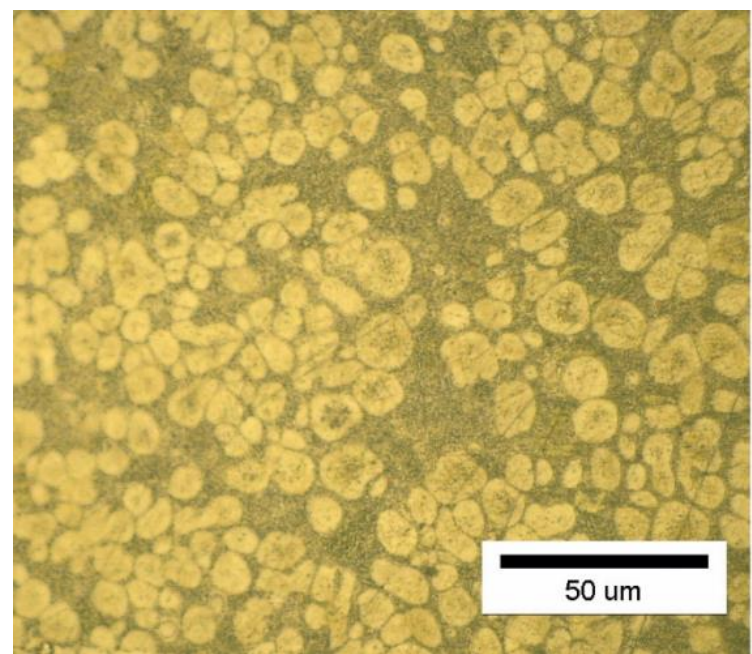

Fig. 5. Microstructure of casting

\section{Numerical model of the process of tightening the load in the belt tensioner element}

In order to determine the internal stress caused by the pyrotechnic charge clamping process, a numerical model of the clamping process was made in the tensioner body. Simufact.Forming software was used to make the model. Since the analyzed part of the tensioner body can be roughly treated as axisymmetric, 2Daxisymmetric case studies were performed. The view of the model is shown in figure 6 .

All model elements except the tensioner body have been modeled as perfectly rigid bodies. The body was modeled as elastic-plastic. Reinforcement curves describing the strain-stress relationship are shown in figure 7.
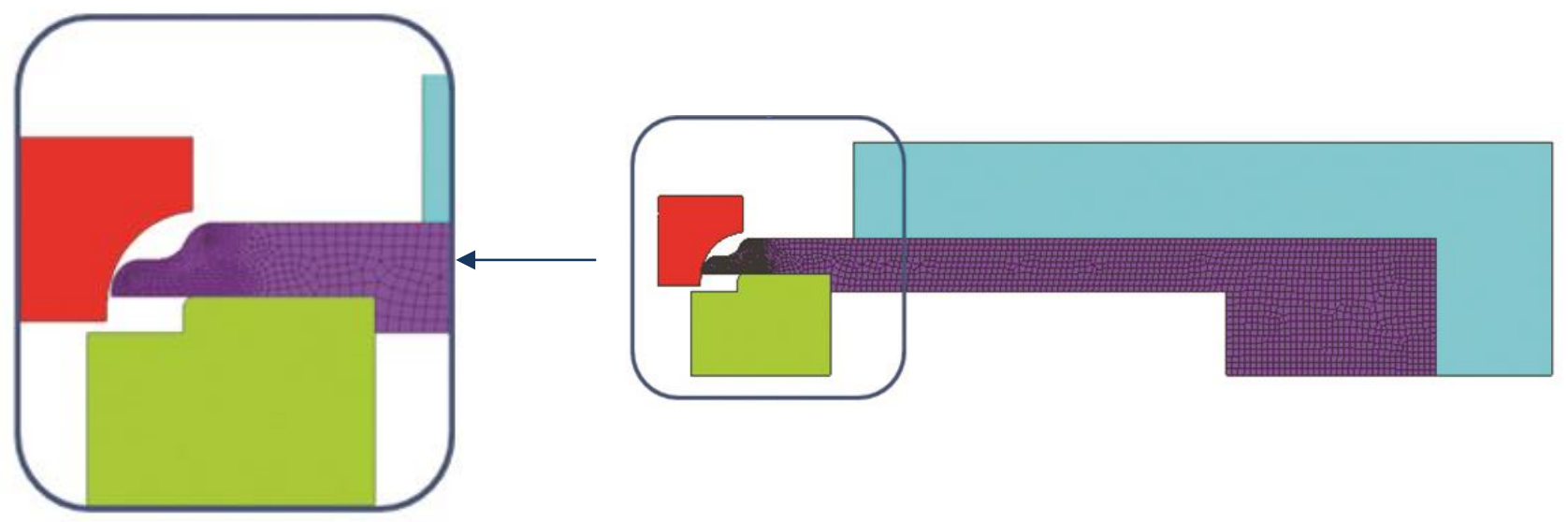

Fig. 6. View of the model of the pyrotechnic charge clamping in the tensioner body

As a result of calculations, distributions of strains and stresses in the body were obtained after the shaping tools were withdrawn. Figure $8 \mathrm{c}$ shows the distribution of equivalent deformations. Since the material shows weakness due to plastic deformation (Fig. 7), the area where the greatest deformation amplitude occurs will be the weakest in the clamping zone. Figures $8 \mathrm{a}$ and $8 \mathrm{~b}$ show stress distribution in the main directions after unloading the shaped material. In both areas marked with a circle, tensile stress occurs in both cases. This state of stress will promote the development of a crack, which may occur as a result of the interaction of the container with the pyrotechnic charge after initiating the belt tensioning process. 

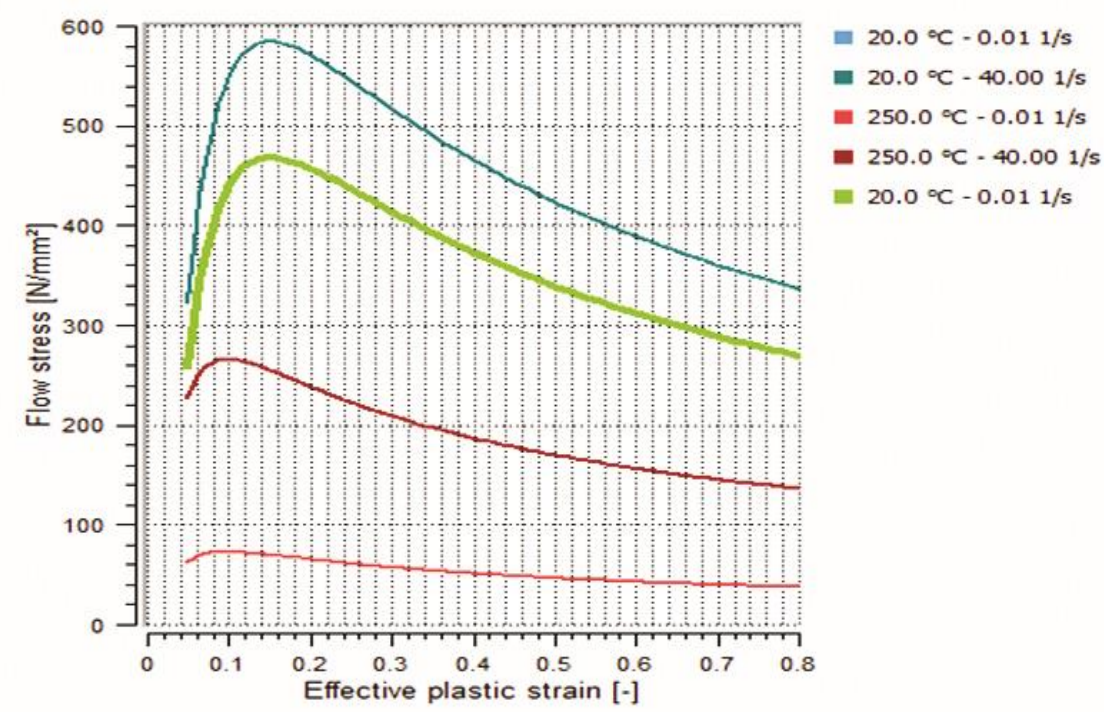

Fig. 7. Strain-plasticizing stress ratio for $\mathrm{ZnAl}$ alloy

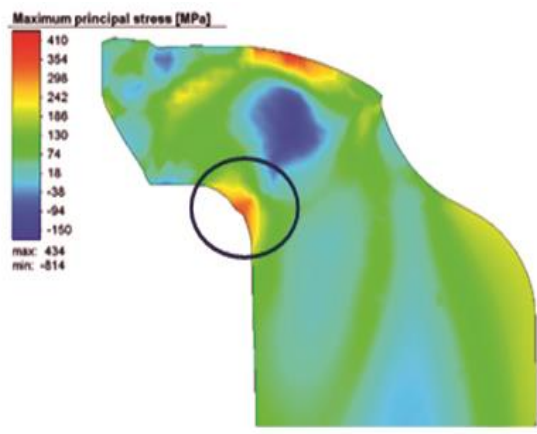

(a)

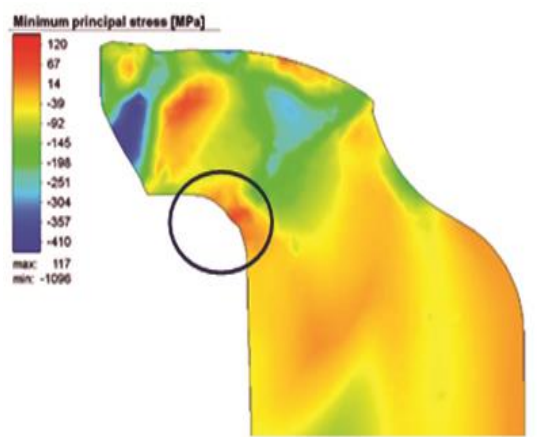

(b)

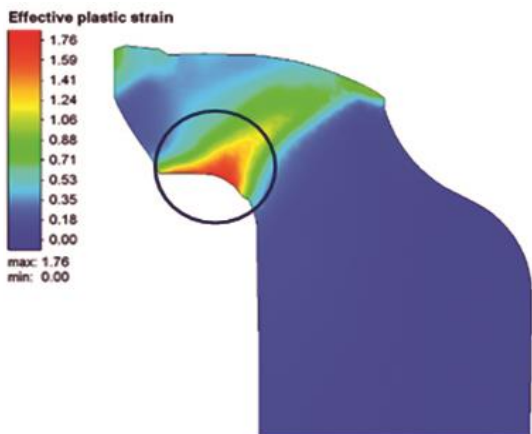

(c)

Fig. 8. Simulation results: a, b) Stress distribution in the main directions after the crimping process and tool retraction; c) Plastic deformation distribution of the crimping process

\section{Summary and Conclusions}

The performed material tests confirmed the correctness of the cast material designation, which was additionally confirmed by the material structure analysis. The cast was made of zinc alloy marked ZP0410. Metallographic tests have shown discontinuities in the structure of the entire examined element, which is characteristic for pressure castings and suggests a high gas content in the mold or metal [2]. Limiting the degree of porosity can be introduced at the stage of selecting a material for a pressure casting. Literature analysis confirms that microstructure shaping has a significant impact on the properties of pressure casting. $[9,12,18]$. The reason for the cast porosity may be due to the mold's structure or pressure casting parameters. Carrying out numerical simulations allows levelling structural errors of the molds [17]. In order to avoid the gassing of the mold, vacuum systems are used to remove air from the mold's cavity $[13,16]$.

As a result of the simulation of plastic forming aimed at immobilizing the pyrotechnic charge, it was demonstrated that during this operation we introduce stresses that favor the formation of cracks due to the force resulting from the detonation of the charge. In the case of high porosity of the casting and additional stress, it can be stated that in extreme cases it may lead to cracking of the casting. Analyzing other design solutions of seat belt tensioners, it has been noticed that a large number of solutions are based on the elimination of plastic forming by using a nut clamping the pyrotechnic cartridge to the body, which can significantly reduce the impact of structure porosity on the final strength of the connection. Another method may be a different technique for making the body, e.g. the use of powder metallurgy [1].

Author Contributions: conceptualization A.S. and P.C.; methodology K.R.; software A.S.; validation A.S., P.C. and K.R.; formal analysis A.S.; investigation P.C.; resources K.R.; data curation P.C.; writing-original draft preparation A.S.; writing-review and editing A.S.; visualization P.C.; supervision A.S.; project administration A.S.; funding acquisition A.S. 
Funding: The research was financed from the statutory fund of Warsaw University of Technology.

Conflicts of Interest: The authors declare no conflict of interest.

\section{References}

[1] Azizi A., Haghighi G.G., Fabrication of ZAMAK 2 alloys by powder metallurgy process. Int J Adv Manuf Technol, 2015, Vol. 77, 2059-2065. https://doi.org/10.1007/s00170-014-6611-z

[2] Czerwińska K., Pacana A., Siwiec D., Analysis of incompatibility of wheel castings for passenger cars. AutobusyTechnika, Eksploatacja, Systemy Transportowe, 2018, Vol. 220(6), 388-392.

[3] Dudek P., Fajkiel A., Reguła T., Kranc M., VI International Scientific Conference INNOWACJE W ODLEWNICTWIE CIŚNIENIOWYM, At Janów Lubelski, Poland, May 2013, IV, 7-18.

[4] Fabijański M., Multiple processing of polylactide. Przem. Chem., 2016, 95(4), 874-876. https://doi.org/10.15199/62.2016.4.33

[5] Gelfi M., Bontempi E., Pola A., Roberti R., Rollez D. and Depero L., Microstructural and Mechanical Properties of Zinc Die Casting Alloys. Adv. Eng. Mater., 2004, Vol. 6, 818-822. https://doi.org/10.1002/adem.200400087

[6] Jasztal M., Nadra A., Milczarek M., Modeling and simulation of the functioning of selected passive safety devices of motor vehicles. Mechanik, 2014, 87(7CD), 247-262.

[7] Jaś-Nowopolska M., Selected actions leading to reduction of emissions from passenger cars. Przeglad Prawa Ochrony Środowiska, 2014, Vol. 1, 201. https://doi.org/10.12775/ppos.2014.008

[8] Kozłowski J., Kochański A., Perzyk M., Tryznowski M., Application of PLA as a Binder in Molding and Core Sands. Archives of Foundry Engineering, 2014, Vol. 14(2), 51-54.

[9] Krajewski W. K., Greer A. L., Krajewski P. K., Trends in the Development of High-Aluminium Zinc Alloys of Stable Structure and Properties. Archives of Metallurgy and Materials, 2013, 58(3), 845-847. https://doi.org/10.2478/amm-2013-0084

[10] Krawiec F. (Ed.), Renewable energy sources in the light of the global energy crisis: selected problems. 2010, Difin.

[11] Lewandowski W. M., Pro-ecological renewable energy sources. 322-347, WNT 2012.

[12] Liu Y., Geng C., Zhu Y., Chen X., Effect of Sr addition on microstructure evolution and mechanical properties of Zn4\% Al hypoeutectic alloy. Journal of Alloys and Compounds, 2017, 695, 443-451. https://doi.org/10.1016/j.jallcom.2016.11.096

[13] Łuszczak M., Dańko, R., Stan zagadnienia w zakresie odlewania dużych odlewów strukturalnych ze stopów aluminium. Archives of Foundry Engineering, 2013, 13.

[14] Mills K., Davis J. R., Destefani J. D., Metallography and Microstructures. Vol. 9. Metals Handbok. (Book). American Society for Metals, 775, 1985.

[15] Niekurzak M., Kubińksa-Jabcoń E., The use of modern materials used in the automotive industry to improve the quality and safety of motor vehicles. Autobusy: technika, eksploatacja, systemy transportowe, 2019, 20.

[16] Pacyniak T., Dudek P., Walczak W., Wrzała K., Innovatory production line of die castings of a significantly decreased porosity. Przeglad Odlewnictwa, 2020, Vol. 70(1-2), 12-13.

[17] Page M. A. M., Ruf M., Hartmann S., Numerical modeling of the thickness dependence of zinc die-cast materials. Computational Mechanics, 2017, 62(4), 655-667. https://doi.org/10.1007/s00466-017-1519-8

[18] Valdez S., Pérez R., Rodriguez-Diaz R.A., Angeles-Chávez C., Casolco S.R., Relationship between silver concentration with microstructural and mechanical properties of rolled AlZn alloy. Materials Science and Engineering: A, 2010, Vol. 527(13-14), 3085-3090. https://doi.org/10.1016/j.msea.2010.02.017

[19] Soroczyński A. Regeneration of Foundry and Core Masses. Journal of Manufacturing Technologies, 2018, Vol. 41(4), 29-33. [Hyperlink]

[20] Soroczyński A., Haratym, R., Rechowicz K., Energy intensity as an ecological factor in the selection of the manufacturing process. Welding Technology Review, 2019, Vol. 91(3), 32-36. https://doi.org/10.26628/wtr.v91i3.1044

(C) 2020 by the authors. Submitted for possible open access publication under the terms and conditions of the Creative Commons Attribution (CC BY) license (http://creativecommons.org/licenses/by/4.0/). 